\title{
Participation or Exploitation: How Can Concepts of Community and Privatization Coalesce around Water Efficiency Approaches?
}

\author{
Mary Gearey ${ }^{1 *}$ \\ ${ }^{1}$ School of Environment and Technology, University of Brighton, Lewes Road, Brighton, BN2 4GJ, UK.
}

Author's contribution

The sole author designed, analyzed and interpreted and prepared the manuscript.

Article Information

DOI: 10.9734/BJECC/2016/18186

Review Article

Received $8^{\text {th }}$ April 2015

Accepted $18^{\text {th }}$ December 2015

Published 25 ${ }^{\text {th }}$ August 2016

\section{ABSTRACT}

The need to promote water efficient technologies and initiatives is increasingly a central feature of Integrated Water Resources Management (IWRM). Attendant to this is a growing focus by IWRM practitioners of the role that community plays in supporting a range of interventions that reduces overall water demand. Public information campaigns led by municipal authorities and water companies encourage water users to become involved in resource husbandry both inside and outside the home. Community participation is encouraged through community water reuse schemes, fundraising campaigns to build community scale water efficient interventions, and NGO, regulator and water company education activities to promote lifestyle changes which support water efficiency endeavours. Whilst there is a clear rationale for involving the community in water management, critical questions should be posed around the way in which this community participation is valued, particularly within privatized water resource management regimes. Does the drive to maximise water efficiency encourage participation or is it an "exploitation" of goodwill? Who derives the maximum utility from this approach; water stakeholders or water company shareholders? Exploring concepts of household revenue streams, Human Scale Development (HSD) and the Transition Network Movement (TNM), this paper advocates an approach that repositions water efficiency initiatives in such a way that ensures that community participation efforts are sufficiently rewarded within socially and environmentally sustainable markets.

Keywords: Community participation; human scale development; water efficiency; transition network movement. 


\section{INTRODUCTION}

This paper explores the way in which approaches to embed water efficiency initiatives within society have been compromised by the marketization of water provision. Focusing on the English experience of modern water provision from the 1980s up to the present, this paper argues that it may be possible to reconcile private sector water supply with community participation through an application of Human Scale Development thinking and practice. The paper will be developed in three sections: The first section will undertake an exploration of what is meant by water efficiency approaches and the political, social and environmental dimensions of adopting water efficient approaches. We begin by outlining the state hydraulic paradigm and its transformation by models of neo-liberal economics and environmental concerns. We will sketch out the formal structure of the regulatory regime, that whilst it operates within the context of the nation state it is part of a world where commodities and finance move freely in globalised markets. We will examine how the privatised structure of the English water supply sector threatens to create an impasse for water efficiency initiatives by disaggregating water use from water bills. This in turn creates a situation in which behaviours which support water efficiency, and which are, by turn, constructed as community participation, are out of step with the need for water companies to ensure they generate profits for their shareholders. If customers are encouraged to use less water then profits can only be maintained through reducing costs or through raising the prices of either the commodity, water, or the service which provides that water. Given that reducing costs are invisible to consumers and only rising prices are tangible then this can be said to place strain on the supplier-consumer relationship. One way of understanding this is as a 'legitimacy gap', or occlusion of trust, between supplier and consumer. This 'legitimacy gap' will be further explored within the paper.

The second section turns to examine these problems in a little more detail. After looking at fundamental problems around the pricing of water, the argument turns to review the way in which various technical solutions have been proposed for dealing with water efficiency and encouraging changes in consumer behaviour. In particular we will look at the way in which discourses of water efficiency relate to those of water conservation. Above all, we will be concerned with the notion of civic engagement which is an important concept utilised by the water companies, and regulatory bodies, when promoting water efficient approaches. To some extent, these notions of civic engagement must be placed in the context of stake-holding, and even 'The Big Society', in that they are concerned with re-invigorating civil society involvement in the process of governance and the role of community participation in markets. However, we will not pursue the historical derivation of civic engagement in any great detail. We will, rather, present water company and regulatory authority involvement in civic engagement campaigns as an attempt to foster a kind of ethics of consumption. This ethics promotes a message in which individual consumers are asked to take responsibility for shaping the trajectory of national water use through accumulative effects of personal or institutional and organisational choice around water use. Effectively the state becomes delinked from water consumption through the narrative of water efficiency. The ramifications of this new ethics of consumption will be explored within the context of neo-liberalism.

The third part of the paper argues that this commodified form of civic engagement is not truly authentic and will not be able to sustain deep seated changes in patterns of consumption and water efficiency. The argument will explore an alternative approach to community participation - the 'Human Scale Development' [HSD] model [1]. HSD comes out of alternative models of development, most notably the work of Manfred Max-Neef and Karl Polanyi [2]. We will argue that it can be linked to contemporary developments in forms of community reward schemes and profit sharing which support new alternative models of civic life. These alternative forms of mutually supportive economic collectivity are typified by the rapid development of the Transition Network Movement (TNM). TNM advocates small scale collective action to support forms of social and economic production which support sustainable livelihoods. HSD, as understood as the theoretical backbone to the TNM endeavour, thus offers an understanding of participation in civic life based on a more radical appreciation of the need to embed markets within social relations. This difference, between an ethics of consumption which asks the consumer to change but does not address the need to reframe the wider economic system, is the central crux to the paper. It is necessary to map a new approach to water efficiency initiatives that 
operates in a context where privatised and highly regulated water regimes close the 'legitimacy gap' [3] through ongoing support of sustainable business practices and community relationships.

\subsection{Section 1: Water Efficiency and the 'State Hydraulic' Paradigm}

Our starting point is the state hydraulic paradigm (SHP) that has informed discourses of water governance in the modern period. In England this can be identified by the advent of a comprehensive water and sewerage system developed in the Victorian industrial era, grounded in public health concerns which, by turn, sustains an active labour force by preventing water-borne epidemics such as cholera and typhoid. At the centre of this global paradigm is the notion that economic development is supported through the provision of cheap water [4]. Sauri and del Moral [5] have described SHP as being characterised by 'state based resource regulation of surface water with the ultimate objective of ensuring cheap water availability for economic growth'. Central to the SHP approach is the connection between economic development, water resources and food sovereignty. For many countries in the post World War Two era cheap domestic water and economic development were inextricably linked. Fundamentally the state was able to provide cheap water through cross subsidisation. Tax revenue enabled the investment in the large capital works and pipelines needed for universal potable water delivery. Domestic orientated state planning, emblematic of many developed and developing economies in the Post War era, which supported national development to reduce international balance of payments deficits, held SHP as a fundamental tenet.

The SHP model, cheap water to support recovering or fledgling economies industrialise and develop, is compromised by the water efficiency narrative. Water efficiency can be understood as a two step process that seeks to reduce the overall volume of the resource used and to do more with that water once it is within the water network [6]. Water efficiency approaches can be structural, the realignment at a national level of developmental goals away from water intensive industries or agricultural products as a means of protecting national water resources, or pitched at the level of interventions through the introduction to consumer markets of low water use and reuse technologies or through education campaigns to alter water using behaviour, attitudes and practises. In essence water efficiency can only be concerned with linking use directly with cost- a marked difference from the SHP model.

For developed economies, at the political scale, water efficiency then marks a movement away from the ethos of the state hydraulic paradigm. The financial subtext behind water efficiency is that by keeping water artificially cheap there will always be an ever increasing demand profile. In reality, the difficulties of manipulating large scale economic readjustment towards optimal water efficiency practises tends to preclude abrupt shifts in water pricing. Instead piecemeal policy instruments to introduce water efficient approaches which are cross scalar and occur over long time periods are more palatable [7]. Water efficiency is then introduced by governments in episodic and iterative phases which according to Cosgrove and Loucks creates policy circularity not innovation: 'Past investments and education tend to perpetuate a way of thinking among people, causing them to formulate and execute policies even if they are inferior to known alternatives' (Cosgrove and Loucks: 2015: 4828) [8].

In recent years, as neo-liberalism has expanded, SHP has been significantly downscaled in many economies with the state seeking to reduce its tax burden through collaboration with the private sector. In this new private-public paradigm, markets are seen as the engine which support and drive water efficient technologies and practises. The wider reasons for this shift remain outside the scope of this paper, but, they can at least be sketched as the influence of neo-liberal models of semi and fully privatised water provision, and, environmental concerns around scarcity and security of water.

However, the point that we want to focus on for the moment is the way in which neo-liberal models of water provision, through the use of privatised markets, has become popular, particularly for urban water services throughout the globe. The role of water efficiency approaches within quasi-privatised markets will be sketched out as follows. Our comments will focus on water provision in England as, at least as far as the neo-liberal model is concerned, this is by far the most developed. The key point is that a market for water exists within a multiscaler regulatory regime defined by domestic and European law. Three key pieces of legislation have shaped the current status quo; the 1989 
Water Companies Act, the 1991 Water Industry Act and the European Union's Water Framework Directive $2000 \quad[9,10,11]$. The 1989 Water Companies Act established the only fully privatised water supply regime in the world, albeit within a tight regulatory framework. The 1991 Water Industry Act set in place the foundations for competition within the water industry. The 2000 EU Directive implemented, amongst other policy goals, water supply benchmarks and conditionality, increased stakeholder participation in decision making and aim for all aquatic environments to be deemed 'good status' by 2015.

Since 1993 each water company has had a duty under section 93A of the 1991 Water Industry Act to promote water efficiency to its customers. Innovative approaches such as reverse water auctions and water trading licences recommended in the 2009 independent review of competition and innovation in water markets [12] (known as the Cave Review) have been incorporated into the new Water Act passed in May 2014. This has adjusted the landscape to the extent that increased options to widen competitiveness will drive efficiency in costs and resource deployment. The 2014 Water Act's most direct impact in terms of community water efficiency is its clarification that the building and maintenance of Sustainable Drainage Systems (SuDS) can be a function of sewerage undertaking. It effectively propels water efficient urban landscaping into the mainstream [13]. Following on from these pieces of legislation, the submission of the Water Resource Management Plans (WRMPs) of the water companies is fundamental to embedding water efficient practises. The WRMPs enable long-term planning for predictable supply and demand forecasts. The process of collecting all WRMPs for 2015-2040 was completed at the end of 2014 and involved customer liaison to assess domestic, agricultural and industrial water needs.

Education campaigns supporting water efficiency have emphasised both the importance of reducing water consumption at home, and the impact of personal use on the wider water environment. Water users have been transformed into stakeholders. The role of the Water Framework Directive (WFD) in empowering local water stakeholders at the catchment level has been well documented $[14,15]$ and complements water efficiency initiatives. The formalisation of these working relationships between water companies, water regulators, NGOS and community action groups, has created unique clusters of water stewardship along individual river catchments (including the formation of Flood Advisory Groups and the Internal Drainage Boards network which work regionally but independently of each other).

Another key reference point is the international adoption in 1992 at the Earth Summit in Rio de Janeiro of the principles of Integrated Water Resources Management (IWRM). In essence the four key tenets of IWRM are that water is finite and vulnerable; that its governance must be participatory, that this must include the contribution of women and that water must be valued as an economic good. IWRM, and more latterly Adaptive Water Management (AWM), which incorporates an iterative learning perspective to the IWRM principles, thus support sustainable and equitable practises around water use. Water efficiency is thus a key tenet of the IWRM/AWM approach which is now embedded within the WFD and hence Europe wide.

Many studies have shown that water users have historically viewed potable water as a plentiful, cheap resource and a very different utility from that of gas or electricity $[16,17]$. Climate change arguments have helped to reposition the water efficiency thrust of 'doing more with less'. It is clear that education campaigns regarding the water cycle and the process of water delivery have made consumers more aware of the pertinence of the water efficiency agenda. Whilst water remains unmetered for many consumers in England, and so water use and water bills are delinked, IWRM and AWM seek to further the cause of water efficiency and community adaptation to increasingly water stressed environments.

Water efficiency practices, technologies and policies are thus primarily understood to take place within the boundaries of the nation state. However, managing water resources increasingly involves both transboundary and international relationships between states. Put another way, water efficiency has become a global concern. There are a number of reasons for this development. Global marketization of water services is ever more prevalent $[18,19,20]$. Global marketization of water services refers to the way in which national water systems are increasingly owned, managed and financed through private enterprise [21]. The shareholders of these enterprises are global citizens, and, increasingly, the private enterprises themselves 
are international water companies with global reach.

This move from the 1980s onwards away from state ownership towards the private sector provision of water services, supported through the neo-liberal agenda of the International Monetary Fund (IMF) and the International Bank for Reconstruction and Development (known colloquially as the World Bank), extends beyond developing economies. For developed economies key financing issues lie around both maintaining ageing capital works, such as sewerage systems, pumping stations and water treatment works and around developing or augmenting alternative water resources such as managed artificial groundwater recharge or wastewater reclamation. In many countries private water companies have taken on the ownership/management roles of water supply and wastewater treatment in urban areas. This can be observed in France, Spain, Chile, Czech Republic and Ghana amongst other nations. Private involvement in water supply and management takes place within a highly regulated context in which the wider responsibility for protecting water environments remains under state control. However, only in England is water provision across all rural and urban areas fully privatised. This revolution began with Margaret Thatcher's governments 1979-1990, but has been carried forward since then by both the Labour Party and current Conservative Party regimes. Privatisation of water in England is geared to a full-cost-recovery paradigm that has replaced the model of crosssubsidisation between state run sectors. As water is crucial for business viability across sectors, industrial, agricultural, manufacturing amongst others, many argue that involving the private sector in water management is a strategically sound move which allows risk sharing across both civic, state and private sectors [22].

Against this backdrop of privatisation lies a fundamental challenge; the company 'asset' is a natural resource and one which is prone to variation in terms of quantity, quality and the timing of availability. IWRM then necessarily operates within a framework of managed risk. Whilst rainfall profiles remain reliable there still exist a number of threats with regards to assured supply due to the vagaries of the hydrological cycle. In other words, disrupted supply is to be expected when managing natural resources such as water. The English water management regime has to respond to disproportionate rainfall levels, whereby the North West, especially the Lake District, receives around $3200 \mathrm{~mm}$ per annum compared to Eastern England which has on average $500 \mathrm{~mm}$ per annum. The more densely populated South East of England, in particular London, receives $514 \mathrm{~mm}$ of rainfall per annum as opposed to Cardiff at $1151 \mathrm{~mm}$ per annum [23]. Changing water conditions indicate that erratic rainfall events are likely to become more episodic [24]. Water efficiency initiatives, and community responses, are impacted by the perception, and the experience, of scarcity. In other words, nothing drives home the need for water efficient approaches than the experience of disrupted supply. Yet as water services are delivered through private, profit making companies there is a change of expectations. The very element of profit changes the relationship between water manager and water stakeholder to that of water 'producer' and water consumer, with customer 'rights' to water very much at the forefront.

Consider the monopoly structure of the English water market. The monopoly structure, based at the geographical scale of river basins, works in parallel with national regulatory bodies, such as the Environment Agency. Aside from large volumetric users at an industrial scale, water users cannot opt out from their service providers: for instance, customers in London can only buy their water from Thames Water. As a result Thames Water now use household revenue streams as a locked-in, assured form of income; they use these assured revenues as a guarantee against their wider corporate debt restructuring [25]. In other words, London water customers finance the long-term investment of their providers' other investment strategies. Macquarie Bank, which own Thames Water, use London water users' money to finance investments in other capital markets because that money is a predictable, guaranteed revenue stream income and so can be treated almost as an asset of the business. Guaranteed water use shores up the wider company investment portfolio.

We will return to this theme, and the 'legitimacy gap' that it potentially opens up, later in this paper. For the moment we want to consider another central issue in the commodification of water. Privatisation is based on the notion that a natural resource, which is prone to variation in terms of quantity, quality and timing of availability, is a company 'asset'. However, unlike other commodities water is limited in supply. This 
fact makes for certain problems. For instance, as water demand projections continue to rise water supply profiles remain relatively stagnant [26]. The crucial issue is: how can private water companies reconcile increased demand with compromised supply? It may be possible to resolve this dilemma by influencing the demand for water. Whilst demand profiles are flexible, influencing demand requires a step change. Consumers must be persuaded to change their behaviour and do more with less water. Moreover, customer behaviour can be motivated in this direction by showing consumers that using less water will cost them less. However, as full cost recovery becomes embedded in operational practice this is not necessarily the case [27]. This is because - irrespective of consumer behaviourother factors influence costs. As cross subsidisation from water services declines, and as regulatory strictures regarding pricing structures relax [28], the cost of water provision rises. We can consider this issue in a little more detail.

For householders and business users, a central water efficiency incentive is saving money through reduction of water and energy use. The Energy Savings Trust state that $55 \%$ of water used in the home is heated water. Hence, using less water means less gas or electricity use [29]. Water efficiency initiatives have championed water meterage as a fundamental tool in reducing water use; enabling users to clearly see their volumetric consumption. Before 2004 approximately $20 \%$ of English and Welsh homes were metered. Since 2004 around 40\% of homes, and $95 \%$ of businesses are now metered; a growth of $200 \%$ [30]. So have water users seen a reduction in their bills since they are more aware of their volumetric use? This question is pertinent since the Water Industry Act 1999 enables water companies to 'universally meter households if the water company's area has been determined to be in an area of serious water stress' [31]. However, increased metering has not seen a corresponding fall in water bills. The 2009 Cave review noted that in real terms domestic English and Welsh water bills rose by $42 \%$ in the 20 years since privatisation. The National Audit Office recorded domestic water bills as rising between 2002-2011 [32]. This flattened out use-cost relationship is further compromised by the difficulties in delivering water due to its complex infrastructure. Water efficiency approaches appear ineffectual when we see that the leakage rates of the water companies remain at $25.6 \%$ for Thames Water,
$16 \%$ for Southern Water and $26.7 \%$ for Severn Trent Water [33]. For Thames Water, in a water stressed area, that is the equivalent of 665 million litres of drinking water wasted every day. These may be renamed as 'returns to the system' by the water companies, but as this is treated potable water, the Thames Water figure alone is the equivalent of 44 million toilets being unnecessarily flushed every day in the Thames Water region.

But it is not just domestic water bills that need reviewing. According to the Food and Agricultural Organisation [34] the domestic consumption sector accounts for only $12.2 \%$ of overall usage. Agriculture use (in the form of livestock and irrigation watering) accounts for $64.6 \%$ of fresh water withdrawals and industrial use (including energy production) accounts for $23.2 \%$. Water efficiency is scalar - the biggest savings are to be made outside of the domestic sector. This throws up some political problems. To integrate water efficiency at all levels of the economy involves radical changes to society; potentially through restructuring agriculture and industry. Whilst these are largely outside the terms of the argument of this paper, they are worth touching upon. For instance, and to imagine a dramatic alternative, it may be possible to give up agriculture altogether and import all food products. In taking this approach, a developed country could instantly reclaim almost two thirds of its agricultural water through the importing of this 'virtual water' [35]. But forgoing food sovereignty is a contentious concept and one which only the wealthier and water scarce nations embrace [36]. Again, we see that approaches to water efficiency involve political will, financial security (in order to pay the resulting balance of payments debt) and a long term perspective to redirect economic productivity away from agricultural production. This, of course, has dramatic social consequences [37].

Yet the dominant narratives that support water efficiency, particularly within Europe, are orientated around water saving technologies and mindfulness in water use. They sidestep the big issues of radical societal restructuring and target the actions of individuals and organisations instead. This emphasis on small-scale social engineering returns our focus to domestic users and a nest of embedded problems. The fundamental issue is identified by Allen and Pryke [38]. They point out that 'the actual cost of water itself and the amount used do not 
themselves seem to figure as part of the financial equation". Indeed, there is an important 'disconnect' in the equation between the price of water and water use. In other words, the service and delivery charge in water bills forms the bulk of the cost: actual volumetric water use is a relatively insignificant sum. The actual volumes of water used by consumers seem then almost an irrelevance. There are other issues. Scaling up to include the involvement of the regulators, Helm and Tindall [39] go on to argue that the volumes of water involved do not figure in the landscape of the five year planning cycle for water pricing. Allen and Pryke note: 'Ofwat determines household water bills on the basis of how much the water companies invest, whether that is raised through equity or debt' [40]. Ofwat state in their 2009 Price Review: 'Promoting water efficiency will not affect company revenues. The revenue correction mechanism, which we will introduce from 2010-2011 will make sure that companies are not penalised if consumers use less water then we assume when we set price limits at PR09' [41]. Delinking water use from the make up of water bills resites water efficiency initiatives as a potential further exploitation of community participation in water stewardship.

This delinkage creates a number of potential 'legitimacy gap' challenges for customer management. In other words, water companies need to make it clear that less water use may result in enhanced water resources even if it is not possible to demonstrate a corresponding drop in the water bills that users receive. Water companies also need to deal with another challenge. Rising profits from the water sector fuel investment opportunities in other sectors, other countries [42]. There is a problem in squaring water efficiency, which, by its very definition, is locked into a distinct geographical scale, with the realities of shareholder capital ready to move with the next investment opportunity. Water may be utilised more efficiently in the home, in the catchment or in a region, yet the shareholders who help finance the water companies reside elsewhere geographically and are primarily interested in future revenue, not necessarily in protecting the original resource and its environment. The challenges faced in these quasi-privatised water markets do not end there. For urban customers, particularly in the European context of financial austerity, there is the risk of default in paying water bills. For those communities in peri-urban and rural environments there is also the public health concern created by those consumers who wish to go 'off grid' and sink their own boreholes to avoid rising costs [43]. Clearly the issue of water pricing and water use are delicately balanced.

There are other issues that impact on water efficiency that we need to consider outside of a strictly economic context. Discourses and practices around water efficiency have a problematic relationship with notions of water conservation. Water efficiency is not coterminous with water conservation, though the two have significant overlap, and both fit within the remit of water governance or 'stewardship'. Water conservation terminology and practices are generally deployed during time sensitive events such as a drought and are exemplified by water use restrictions, such as a time limit on garden watering and car washing or a physical reduction in access such as rediverting potable supplies to communal standpipes. We can crudely differentiate water conservation from water efficiency by describing the former as a short term response to water-demand / water-supply crises, and water efficiency as a long term holistic approach to managing water resources. There is a wide literature on both water efficiency and water conservation which this paper does not have the scope to examine thoroughly. Our key point here is that water efficiency and water conservation have been brought together in discourses around the use of technology. Whilst the use of technology certainly can improve both use and management of water resources, it is arguably the case that water companies relying on technological solutions effectively distance themselves from political issues around the relationship between communities of water users and privatised water providers; issues that will not go away.

\subsection{Section 2: Water Efficiency, Technology and Civic Engagement}

Our argument in this section of the paper rests on the assertion that technological innovations which support water efficiency are only effective if the people and communities utilising them are prepared to make profound changes to their behaviour and their practises. As Table 1 shows, water efficient technologies range from household adaptations - dual flush / low flush toilets, aerating taps and rainwater harvesting systems, to industrial adaptations - water recycling within cooling systems, automatic water meter reading and digital monitors to detect 
leaks. City scale 'water sensitive' innovations which augment wastewater reuse and support closed loop systems in which water is recirculated and reused many times before returning to the environment are also in development [44].

Adopting new technologies, and adjusting use, practice and behaviour accordingly, entails what could be called a 'deep seated' shift in the consciousness of water users. It is certainly true that water conservation approaches can encourage this type of behavioural change, but there are limits. The focus of water conservation is on the short-term protection of the resource rather than a long-term volumetric reduction of use. Once the threat to the water resource is resolved, the notion of 'back to normal' may undo any positive change. The focus of water efficiency addresses individual action whether at home, at work, or in the community. Water efficiency concerns behavioural change in the context of water-demand/ water-supply challenges. It requires a step-change in water use which is both attitudinal and behavioural. Participation starts at the personal level and scales up to a community wide and ultimately societal scale (see Table 2). From this perspective, water efficiency is bound with community participation, as it links personal water saving actions and behaviours to wider societal goals which support resource integrity. It could be argued that water efficiency brings together notions of civic responsibility with an 'ethics' of consumption, and could also perhaps be linked to green political and social agendas. Requiring customers to engage with water efficiency can thus be 'sold' as a practice that brings together individuals, families, water companies and communities in a process which is furthering a responsibility towards the environment.

Tables 1 and 2 further elaborate these points. We can see that water efficiency interventions and technologies move from the personal to the social, from office spaces to industry. From saving water in the home by changing personal use, toilet flushing and washing habits, to installing technologies such as rainwater butts for garden watering, the scale moves outwards. However, we can further our analysis by turning out attention to a particularly interesting phenomenon: the way in which discourses of water efficiency seek a visibility in public spaces. This meso level engagement has been described by Reid et al. [46] as creating explicit "communities of interest....identifiable by heterogeneity, collective interest and shared social identity." This draws our attention to a subtle form of advertising and promotion. A private organisation has to show that it can bring diverse groups together under a project that it has defined. Clearly, there are different ways in which this can be done- and- it is not restricted to privatised water. Consider, for instance, the way in which oil companies such as BP and Shell sponsor art exhibitions and music festivals. Water companies, likewise, have to show publically that they can occupy civic space and bring together individuals, households and communities in shared endeavours. Why is this necessary?

We need to see the use of public space as a component of a much broader portfolio designed to promote and encourage change in water use. Whilst industrial and agricultural sectors can undergo water audits to display their commitment to reducing water use, the domestic level remains relatively private and inaccessible. Visible civic engagement provides a space in which it is possible to demonstrate the utility of water efficient practises and approaches and to disseminate 'good practice'. Tables 1 and 2 highlight a wide range of community practises that are becoming more popular, These include community allotment and land shares schemes which make use of harvested rain water and hardstanding run off. Also relevant are urban green drainage systems that create community wildlife reserves and community orchards. Rain gardens can also be retrofitted to provide shallow depressions of flowers, shrubs or trees that sit in the urban environment. Rain gardens absorb rainfall run off and attenuate flooding. In the UK they are a relatively recent innovation and complement the SuDS approach for urban water management. They are often managed by partnerships between local authority and community groups, with installation often tax player funded and ongoing maintenance secured through voluntary contributions. Other community water efficient activities include organising awareness events such as water cafes, fundraising for green roofs on community facilities such as schools and village halls, and the formation of community allotments and land share schemes $[47,48]$.

To summarise and elaborate the argument so far. We have seen that the current English water management regime has a tight national regulatory structure imposed on a market for 
commoditised water. The problem of efficiency is rooted in this context. We have seen that for water efficiency to be effective it will have to work at multiple scales. In order to create lasting changes in both individual and social water use, customers must be encouraged to consume and budget for water in different ways. Furthermore, changes in behaviour have to be rooted in communal life. It appears that water companies are looking for civic or community involvement. Whilst water efficiency discourses have some relationship with water conservation ideas and practices, we need to appreciate that the 'bigger picture' is one of episodic and incremental change, and the two discourses exist in a degree of tension. It may be that the two discourses need to be brought together, and that this is precisely the role of civic engagement. Whilst technology is important, what is perhaps most important is an authentic engagement of privatised water providers with a politics of community.

Table 1. Examples of water efficient technologies or behaviours

\begin{tabular}{ll}
\hline Examples of a water efficient technologies & \\
\hline 'Toilet to tap' systems & Eco showerheads \\
Green roofs for water capture & Membrane \& Nano filtration systems \\
Rain gardens & Water Efficient white goods \\
Plant filtration beds & Recycled water irrigation systems \\
Borehole water recirculation systems & Industry scale water reuse systems \\
Water meters/automatic meter readers & Introduction of water hardy plants \\
Storm water storage and release systems & Water efficient irrigation systems \\
Hydroponic systems & Closed loop water networks \\
Digital monitoring systems for leaks & Use of crops with deeper root systems \\
Low flush / dual flush toilets & Crop rotation to support soil percolation \\
Low flow showerheads & Sustainable Drainage Systems (SuDS) for farm \\
'Rain share' schemes & buildings \\
Cistern hogs for toilets & Black water recirculation \\
Digital monitoring systems for leaks & Green roofs: capture run off \& lower energy costs \\
Rainwater harvesting systems & Aquifer augmentation through wastewater \\
Urban drainage for community orchards & injection \\
Alternative cooling systems & Education campaigns to reduce consumption \\
Improved filtration processes for industrial & levels \\
aggregate & Grey water reuse systems \\
Garden water butts & Separation processes for black/grey/yellow water \\
\hline
\end{tabular}

Table 2. Examples of interventions that support water efficiency

\section{Example of interventions that support water efficiency}

Facilitating water efficiency reduction measures in other actors [45]

Advocating for efficient and sustainable practises at local, national and international scales [45]

Networking at conferences and events to promote water efficiency dialogues

Sharing data and information to improve water management systems [45]

Investing in public water infrastructure and upgrades [45]

Using financial and technical resources to support local water institutions [45]

Educational campaigns at schools and public events

Lifestyle change: low meat, low food miles to incorporate virtual water concepts

Block rate pricing rather than flat rate pricing structures for both water and energy (energy highly

water consumptive)

Financial subsidy to support low water use endeavours

Use of Integrated Assessment Model at government planning scale

Financial/policy support for rain fed / drip feed irrigation technology

Trade agreements with water rich countries leading to 'virtual' water transfers of goods and services

Research and Development investment for radical approaches such as reducing reservoir evaporation and promoting rainfall sensitive food markets 
Private companies, reliant on making profit, need to build legitimacy with their consumers [49]. State regulatory structures go some of the way to define the terms of supply [50], but a legitimacy gap still remains [51]. In part this is to do with the local nature of water and the hydrological cycle: some parts of the country experience scarcity, whilst others do not. There are other factors. Water companies and other stakeholders attempt to involve consumers and water users through the perspective of water efficiency and conservation. The championing of water stewardship practices and the need to preserve a special resource are undoubtedly important in the governance 'mix'. However, in a period where public trust of private companies is being tested, it may prove difficult to persuade consumers that companies place the welfare of the commodity above its monetary role in creating profit. Rising bills and evidence of water wastage by the water companies themselves also make the governance regime vulnerable to the criticism that existing policies serve to present water companies as working solely in the interests of their shareholders and investors. Indeed, the role of neo-liberal structures within water management systems has come under considerable criticism [52]. Without serious reconsideration of how the understanding of community operates in water governance, it may be that the idea that there is valid, reciprocal participation becomes completely discredited. In order to prevent this happening, it may be necessary to turn to a different way of thinking about markets and their relationship to community; indeed, there may be a better way to navigate the tensions between water efficiency, community participation and the privatised water sector. In order to elaborate this position, we turn to the insights provided by Human Scale Development theory.

\subsection{Section 3: Water Efficiency and Human Scale Development}

In the section above, we suggested that there was something of a 'legitimacy gap' between water companies and their customers. We do not want to use the concept of legitimacy in detail in this paper but, at least at a common sense level, we want to suggest that privatised providers will not be seen as legitimate if they place their own profits before the provision of an essential resource. Furthermore, initiatives to change water use will not be effective if the customers of water companies fail to engage authentically with a raft of issues. We wish to develop this line of argument further by suggesting that water efficiency initiatives could strengthen the trust between community groups and water management regimes but only through reframing the water efficiency agenda. In other words, water supply companies and regulators must do much more to encourage support by consumers. There needs to be an element of profit sharing, albeit in an alternative form, which recognises and seeks to redress this imbalance.

Our argument borrows from the Human Scale Development (HSD) approach. Drawing on the work of the Chilean economist Manfred MaxNeef, Karl Polanyi [53,54] and other economic anthropologists, Human Scale Development (HSD) begins from the perspective that the continued goal of economic development in a linear trajectory is neither sustainable nor favourable for humans, or indeed, the environment. From this perspective the commodification of water exemplifies the way that a focus on economic development alienates people from their natural environment and, ultimately, from each other. Instead the focus, as Max-Neef has defined it, comes from putting goals such as human dignity, well being and self development before indicators which would otherwise be used to determine national development such as Gross National Product and Poverty Indices. The United Nations' Food and Agricultural Organisation (FAO) have incorporated the need to recognise the social justice aspects of access to freshwater in their position papers, linking water, food security and human dignity together [55]. However, it is important to stress that Human Scale Development does not reject the role and the importance of the market. Rather, it argues that for the market to work it needs to be embedded in social relationships which themselves take priority over wealth accumulation. In short, markets need to work for people.

Admittedly, this requires us to think critically about the small, regulatory state idealised by neo-liberalism. HSD does not abandon the state. The power of the state is necessary to socially embed a market. Unlike New Labour communitarianism, HSD is much more concerned with decentring power in radical and participatory ways. Moreover, ideas of embedded economy are distinct from the present emphasis on formal regulatory regimes. New forms of social co-operation are necessary [56] to supplement such structures. We can elaborate these ideas with reference to the recent 
Waterwise response to a government white paper [57]. Waterwise argue that the current regulatory framework has a supply sided bias: assurity of supply currently takes precedence over water efficiency. They also note that the regulatory system is muscle bound: unable to respond flexibly to changing scenarios both in terms of economic change but also environmental. The numerous planning cycles of various aspects of water provision and planning (drought plans, flood risk management, pricing cycles, Town Planning Acts) reduce innovation and suffocates adaptation. From this metaplanning perspective, how can the privatised elements of water provision coalesce with the concept of community that the WFD is so keen to promote? The term that is reiterated by NGOs, local councils and water companies is 'partnership'. Using water efficiency as a focal point for partnership efforts, it may be possible to rebalance dialogue and action in favour of those community participants at the catchment level.

HSD thinking would further this approach. Bringing together local catchment based support from a diverse range of community members, it may be possible for smaller stakeholders to reassert their expertise in crucial areas, to demonstrate that new partnership approaches may add in the missing flexibility and to plug the gap between municipal, private and grassroots adaptation. Water efficiency may become a much more nuanced discourse, making use of local expertise and local knowledge outside of formal and privatised frameworks. There is a second important theme. HSD approaches seek to recognise the value of unpaid work to the wider economy. The HSD perspective accords with Seyfang and Longhurt's work on community currencies [58]. To move the debate on from 'exploitation' to 'participation', unrecognised work needs to be fully valued - and remunerated, even outside of standard market parameters. Their systematic review of community currencies identified those which generated momentum in 'green' communities (local exchange trading schemes) and those which appeared to demonstrate variety across different economic sectors (time banks) and those which offer sustainable consumption [59]. These initiatives suggest that community resources need strategies to develop them. What forms might these take? One proposed method would be to utilise strategies that support both the local environment and the local economy. Numerous examples show that it is possible to engage communities in projects where an ethical long term outcome, using less water, can match with short term benefits.

The global 'Transition Network Movement' (TNM) can help concretise these ideas [60]. The movement supports local entrepreneurs, consumers and businesses in mutually supportive networks that work at local levels to form global chains of like minded actors. With Transition Networks now established in over 20 countries from its origin in the UK, there are now groups operating across Europe, North and South America and in Australia and New Zealand. The principles on which the Transition Network are based accord with HSD ideas - that human value and capacity should be supported and nurtured and balanced with promoting inclusivity and social justice with respect to natural resources. In other words, human development can only be supported through a custodial relationship with the environment. Water efficiency principles themselves align with this vision of human-nature interactions. One of the practical manifestations of this approach is the idea of local currency - which is used in local businesses and exchanged for services, labour or products. This idea could be applied to water management practices at the community level. In return for water efficient endeavours the regulator, or the water company, depending on the input made and the water savings delivered, could reward local participants, whether shareholders or partners, with this local currency. The Bristol Pound and the Lewes Pound are two existing examples. This currency drives local businesses, both chains and independents, and helps foster a sense of reward in return for participation. Other alternative forms of currency include time-banking and co-production; both new forms of rewarding participation. Local water stakeholders collaborating together may feel more empowered to demand a return for their endeavours, given the monetised environment that some privatised water sectors embody. Examples include vouchers for local shops, direct funding for community projects or apprenticeship schemes to promote youth employment. The nub is that participants gain something tangible as they give something very personal - their time, their expertise, their labour - but that something is idiosyncratic and rooted in the local community. This approach might go some way to highlight that a resource as geographically localised as water cannot be comfortably integrated into international capital markets. HSD moves the debate, and associated action, on from its current position. HSD 
approaches cannot be pilloried as 'anti-market'. The HSD approach seeks to create viable, functional markets that are rooted in social and community relations. Clearly, this resonates with other critical approaches to economics more generally, For instance, critical geographers, such as Noel Castree [61], and David Harvey [62] have drawn attention to a theme from Polanyi. Unless we are able to change habits of consumption, markets risk destroying the very social and environmental structures on which they depend.

These are big issues. Perhaps a case can be made for reducing population size, changing our economy from industrial to knowledge based, reducing our carbon imprint, changing our diets. In short, and in line with Seyfang [63], consuming less. Critics might argue that this is utopian, but, there is a growing body of evidence around issues like climate change that suggest that radical action may be necessary. One thing is perhaps clear. Discourses of water governance have to return to political questions. There are no technological quick fixes. Indeed, we need to realise that water use is part of a much broader and problematic set of concerns. Water governance has to accomodate the values that we hold and the way we choose to live our lives.

A critic might still object. Although $\mathrm{s} /$ he might acknowledge the HSD position in general, the real problem is one of application of HSD thinking to a particular water sector. How, for instance, can HSD thinking be applied to the English water sector? Our arguments above go some way in acknowledging these points, but more could still be said. The key point is that HSD thinking is about how markets operate. If, as we argued above, the resource is an asset of a company, then both companies and consumers need to understand that whilst water is a commodity, it is a very specific commodity. This point is a variation on Polanyi's argument about the fictitious commodities of money, land and labour [64]. Markets must commoditise 'things', resources and 'services' that in premarket societies were not commodities. Commodification risks destroying the very 'things' that it commodifies (for instance, think of currency crises, systemic unemployment and dispossession from land that is both an historical and ongoing problem associated with land markets). We do not have enough room in this paper to elaborate Polanyi's thinking in detail, but there is one essential point that we need to stress. Markets, for Polanyi, are political creations. They cannot be thought of as spontaneous or 'natural' orderings of human affairs. Moreover, unless one acknowledges the inherent problems of marketization, the process of commodification will compromise the very social and environmental supports on which markets rest. One can immediately appreciate how this line of argument might connect with modern thinking about climate change and the limits of growth. We do not wish to pursue this analysis in this paper, we wish instead to focus on what Polanyi tells us about the nature of commodities.

Although Polanyi does not talk about the commodification of water specifically, his argument about commodification of land can be linked to the fear that the commodification of water risks the misuse of the resource. A market for water, and indeed services around water, can only be successful if a company understands that the commodity needs to be 'nurtured'. It is not so much that a company needs to build into its profit profile the sustainability of the resource; rather, without sustainability, there is no resource. This is a radical argument, but it is not an argument against commodification or against markets. It is a fundamental understanding of the nature of the commodity that is being sold. From this perspective it is also the case that civic engagement is not an 'add on' to make a water company appear like a good 'corporate citizen'. Authentic community engagement is the real condition on which a viable market for water can exist in the first place. Returning full circle, water cannot be treated as another commodity, it takes central place in the long-term viability and health of a nation state. Citizens, the state and the water companies must work collectively to protect the resource using water efficiency as a way of conceptualising personal and collective responsibility.

\section{CONCLUSION}

Dominant approaches to water governance have made use of community and civic engagement. For domestic users, water regulators and companies encourage this approach through campaigns to promote taking shorter showers, using water butts and being more mindful when using dishwashers and washing machines. For industrial users, water efficiency is depicted as part of a green agenda, whereby water resources are part of environmentally friendly schema. For agricultural users the drive to become water efficient is linked to a more nuanced relationship 
with the natural environment. For public service or municipal work the adaptation is target driven, reducing use and therefore overheads: thus saving taxpayers' money. The global result is that behavioural change and adaptation to new water efficient technologies encourage a community 'buy in' and a more careful use of a localised resource.

Drawing on Human Scale Development thinking, this paper has argued that discourses on community involvement in water governance need to be re-thought. Water efficiency approaches need to be seen as part of a wider resource management agenda with human development rather than economic development as its central tenet. Through addressing the imbalance between asking water users to use less water whilst seeing no clear, corresponding drop in their water bills, it is hoped that narratives of water efficiency will move away from the accusation of exploiting community good will to those of enabling community participation and securing mutual benefits. Adaptation and innovation needs to assert itself from outside of the current IWRM/AWM regime to enable this narrative change. The large financial gains made by the water companies on international capital markets through the financialisation of household revenue streams threatens to dissolve relationships of trusts between water companies and water users. HSD thinking stresses the importance of decentred and local forms of stewardship and community involvement. Moreover, and perhaps most importantly, the HSD approach argues that any community work around resource stewardship should be recompensed in a way which supports the local economy at the catchment scale. Whilst much more work is necessary to articulate in detail how HSD thinking could reposition water governance, the Transition Network movement and the resources offered by local currencies, has the potential to move community partnership from "exploitation" to genuine forms of participation at the catchment level between regulator, water company and water user.

\section{COMPETING INTERESTS}

Author has declared that no competing interests exist.

\section{REFERENCES}

1. Max-Neef MA. Human scale development: Conception, application and further reflections. New York: Apex Press; 1991.
2. Polyani K. The great transformation: The political and economic origin of our time. New York: Farrar \& Rineheart; 1944.

3. Gearey M, Jeffrey P. Concepts of legitimacy within the context of adaptive water management strategies. Ecological Economics. 2006;60(1):129-137.

4. Bakker K. Neoliberalising nature? Market environmentalism in water supply in England and Wales. Annals of the Association of American Geographers. 2005;95(3):542-565.

5. Sauri D, del Moral L. recent developments in Spanish water policy; Alternatives and conflicts at the end of the hydraulic age. Geoforum. 2001;33(2):351-362.

6. Gleick P. The world's water volume 8: The biennial report on freshwater resources. New York; The Island Press; 2014.

7. Cosgrove WJ, Loucks DP. Water management; current and future challenges and research directions. Water Resources Research. 2015;51(6):48234839.

8. Cosgrove WJ, Loucks DP. Water management; current and future challenges and research directions. Water Resources Research. 2015;51(6):48234839. p: 4828.

9. The Water Act London. The Stationery Office; 1989.

10. Water Industry Act. London. The Stationery Office; 1991.

11. Directive 2000/60/EC of the European Parliament and of the Council establishing a framework for the Community action in the field of water policy.

12. Cave M. Independent review of competition and innovation in water markets: Final report. London; HM Government; 2009.

13. The Water Act. London: The Stationery Office; 2014.

14. De Stefano L. Facing the water framework directive challenges: A baseline of stakeholder participation in the European Union. Journal of Environmental Management. 2010;91(6):1332-1340.

15. Hammer M, Balfors B, Mortberg U, Petersson M, Quin A. Governance of water resources in the phase of change: A case study of the implementation of the EU Water Framework Directive in Sweden. AMBIO: A Journal of the Human Environment. 2011;40:210-220.

16. DEFRA. The Independent Review of Charging for Household Water and 
Sewerage Services. Norwich: HMSO; December; 2009.

17. Vugteveen $\mathrm{P}$, et al. Stakeholder valuations orientations in water management, society and natural resource. An International Journal. 2010;23(9):805-821.

18. Haughton G. Market making: Internationalization and global markets. Environment and Planning A. 2002;34(5): 791-807.

19. Gandy M. Rethinking urban metabolism: water, space and the modern city. City; Analysis of Urban Trends, Culture, Theiry, Policy, Action. 2004;8(3):363-379.

20. Bakker K. Neoliberalising nature? Market environmentalism in water supply in England and Wales. Annals of the Association of American Geographers. 2005;95(3):542-565.

21. Haughton G. Market making: Internationalization and global markets. Environment and Planning A. 2002;34(5): 791-807.

22. Schultze P, Orr S, Morrison J. Shared risks and interests: The case for private sector engagement in water policy and management. In Gleick P. The world's water volume 8: The biennial report on freshwater resources. New York; The Island Press; 2014.

23. MetOffice.

Available:http://www.metoffice.gov.uk/publi c/weather/climate/gcjszevgx

24. Christensen $\mathrm{JH}$, et al. Regional climate projections in climate change 2007: The physical science basis. In: Contribution of working group 1 to the fourth assessment report of the intergovernmental panel on climate change. Cambridge, UK: Cambridge University Press; 2007.

25. Allen J, Pryke M. Financialising household water: thames water, MEIF and 'ringfenced' politics. Cambridge Journal of the Regions, Economy and Society. 2013; 6(3):419-439.

26. Available:http://www.iwmi.cgiar.org/2014/0 8/global-water-demand-projections-pastpresent-future (Accessed on May $23^{\text {rd }}$ 2015).

27. Allen J, Pryke M. Financialising household water: Thames Water, MEIF and 'ringfenced' politics. Cambridge Journal of the Regions, Economy and Society. 2013; 6(3):419-439.

28. The Water Act. London: The Stationery Office; 2014.
29. Energy Saving Trust. At home with water. Accessed $11^{\text {th }}$ June 2014.

Available: www.energysavingtrust.org.uk

30. Environment Agency. Water Resources in England and Wales: Current state and future pressures. Bristol: Environment Agency; December; 2008.

31. South East Water. Making every drop count. Accessed $11^{\text {th }}$ June 2014.

Available:www.makingeverydropcount.co.u k

32. National Audit Office. Infrastructure Investment: The impact on consumer bills. London: The Stationery Office; November; 2013.

33. OFWAT. Leakage performance against targets. London: The Stationery Office; 2010.

34. Available:http://www.fao.org/nr/water/aqua stat/water use/index.stm (Accessed 2nd July 2015).

35. Allen J, Pryke M. Financialising household water: Thames water, MEIF and 'ringfenced' politics. Cambridge Journal of the Regions, Economy and Society. 2013; 6(3):419-439.

36. Chapagain AK, Hoekstra AY. The global component of freshwater demand and supply: An assessment of virtual water flows between nations as a result of trade in agricultural and industrial products. Water International. 2008;33(1):19-32.

37. Lerner AM, Eakin $H$. An obsolete dichotomy: Rethinking the rural-urban interface in terms of food security and production in the global south'. The Geography Journal. 2011;77(4):311-320.

38. Allen J, Pryke M. Financialising household water: Thames Water, MEIF and 'ringfenced' politics. Cambridge Journal of the Regions, Economy and Society. 2013; 6(3):419-439.

39. Helm D, Tindall $T$. The evolution of infrastructure and utility ownership and its implications. Oxford Review of Economic Policy. 2009;25:411-434.

40. Allen J, Pryke M. Financialising household water: Thames water, MEIF and 'ringfenced' politics. Cambridge Journal of the Regions, Economy and Society. 2013; 6(3):419-439.

41. OFWAT. Appendix 1: Water efficiency targets 2010-11 to 2014-15. London: The Stationary Office; 2008.

42. Allen J, Pryke M. Financialising household water: thames Water, MEIF and 'ringfenced' politics. Cambridge Journal of the 
Regions, Economy and Society. 2013;6(3): 419-439.

43. Available:http://www.inishowennews.com/0 12 WaterDivining143 (Accessed on $4^{\text {th }}$ June 2015).

44. Available:http://watersensitivecities.org.au/ what-is-a-water-sensitive-city/ref (Accessed on May $28^{\text {th }}$ 2015).

45. Available:https://www.unglobalcompact.org /docs/issues doc/Environment/ceo water mandate/Guide Responsible Business E ngagement Water Policy.pdf (Accessed on 12th August 2015).

46. Reid L, Sutton P, Hunter C. Theorizing the meso level: The household as a cruicible of pro-environmental behavior. Progress in Human Geography. 2010;34:309-324.

47. Available: www.RainShare.net (Accessed on $7^{\text {th }}$ August 2015).

48. Available: www.Landshare.net (Accessed on $7^{\text {th }}$ August 2015).

49. Gearey M, Jeffrey P. Concepts of legitimacy within the context of adaptive water management strategies. Ecological Economics. 2006;60(1):129-137.

50. The Water Act. London: The Stationery Office; 2014.

51. Gearey M, Jeffrey P. Concepts of legitimacy within the context of adaptive water management strategies. Ecological Economics. 2006;60(1):129-137.

52. Bakker K. The limits of 'neoliberal natures': Debating green neoliberalism. Progress in Human Geography. 2010;34(6):715-735.

53. Max-Neef MA. Human Scale Development: conception, application and further reflections. New York: Apex Press; 1991.
54. Polyani K. The Great Transformation: the political and economic origin of our time. New York: Farrar \& Rineheart; 1944.

55. The Swedish Food and Agricultural Organisation committee. Water, Food Security and Human Dignity: A nutrition perspective. Position paper 10. Stockholm; Sweden; 2015.

56. Hulgard L. Social entrepreneurship. In Hart $\mathrm{K}$, Lavill JL, Cattani AD, editors. The human economy: A citizen's guide. Cambridge: Polity Press; 2010.

57. Waterwise. White paper to the government: Mainstreaming water efficiency in the UK: Helping to meet the challenges of climate change through wasting less water.

Available: www.waterwise.org.uk (Accessed 11 ${ }^{\text {th }}$ June 2014).

58. Seyfang G, Longhurst N. Growing green money? Mapping community currencies for sustainable development. Journal of Ecological Economics. 2013;86:65-77.

59. Seyfang G. The new economics of sustainable consumption. London: Palgrave Macmillan; 2009.

60. Available: www.transitionnetwork.org (Accessed $17^{\text {th }}$ July 2015).

61. Castree N. Making sense of nature. London and New York: Routledge; 2013.

62. Harvey D. A brief history of neoliberalism. Oxford: Oxford University Press; 2005.

63. Seyfang G. The new economics of sustainable consumption. London: Palgrave Macmillan; 2009.

64. Polyani K. The great transformation: The political and economic origin of our time. New York: Farrar \& Rineheart; 1944.

(C) 2016 Gearey; This is an Open Access article distributed under the terms of the Creative Commons Attribution License (http://creativecommons.org/licenses/by/4.0), which permits unrestricted use, distribution, and reproduction in any medium, provided the original work is properly cited. 